\title{
FORGÁCSLEVÁLASZTÁS VIZSGÁLATA KÍSÉRLETEKKEL ÉS SZIMULÁCIÓVAL
}

\section{A STUDY ON CHIP FORMATION BY EXPERIMENTS AND SIMULATION}

\author{
Dezső Gergely ${ }^{1}$, Szigeti Ferenc ${ }^{1}$ \\ ${ }^{I}$ Nyirregyházi Föiskola (Müszaki és Agrártudományi Intézet, Müszaki Alapozó, Fizi- \\ ka és Gépgyártástechnológiai Intézeti Tanszék) H-4400 Nyíregyháza, Sóstói út 31/b \\ Telefon+36-42-599400 / Fax: +36-42-402485,dezsog@nyf.hu
}

\begin{abstract}
In this paper experimental results on chip formation are compared with model calculations. It is shown out that our model gives good results for force demand of planning.

Keywords: cutting, simulation, environmentally consciou

\section{Összefoglalás}

Ebben a tanulmányban a forgácsleválasztással kapcsolatos kísérletek eredményeit vetjük össze modellszámításokkal. Kimutatjuk, hogy az általunk felépített modell jól írja le a gyalulás során fellépő erőszükségletet.
\end{abstract}

Kulcsszavak: forgácsolás, szimuláció, környezettudatos

\section{Bevezetés}

A forgácsképződés során fizikai, kémiai, tribológiai, hidrodinamikai folyamatok egymással egy időben és egymást befolyásolva zajlanak le.

A forgácsképződés folyamatának mélyebb tanulmányozása ezért elengedhetetlen a környezetbarát megmunkálási technológiák fejlesztése szempontjából.

Célunk a fémgyalulás erőszükségletének kísérleti vizsgálata különböző forgácsolási paraméterek esetén.

Célunk továbbá olyan fizikai modell kifejlesztése, amely jó közelítéssel adja meg a gyalulás során a forgácsoló erőt.

\section{A kísérletek körülményei}

A gyalulási kísérleteket forrasztott keményfémlapkás gyalukéssel végeztük, melynek szabványos jelölése: Hajlított forgácsolókés R 2525 MSZ1902:DA20

A próbatest anyaga: S355 JRN MSZ EN 10025 általános rendeltetésü ötvözetlen szerkezeti acél.

A gyalulási kísérleteket szárazon, hütőkenő folyadék alkalmazása nélkül végeztük.

A kísérletek végrehajtása PW 550 tip., lengőhimbás hajtóművel rendelkező harántgyalugépen az alábbi paraméterekkel történt:

- lökethossz: L $=200 \mathrm{~mm}$

- munkadarab hossz: $\mathrm{L}_{1}=122 \mathrm{~mm}$ 
- kettőslöketek száma: $\mathrm{n}_{\mathrm{k}}=22-74$ $\mathrm{kl} /$ perc

- fogásmélység: $\quad a_{p}=0,5-1,5 \mathrm{~mm}$

- oldalirányú előtolás: $\mathrm{f}=0,182 \mathrm{~mm} / \mathrm{kl}$

- átlagos forgácsoló seb.: $\mathrm{v}_{\text {clöket }=}$ $8,8-29,6 \mathrm{~m} / \mathrm{p}$

- tényl. átl. forg. seb.: $\mathrm{v}_{\mathrm{cL}}=$ $10,67-34,86 \mathrm{~m} / \mathrm{p}$

- egy ciklus ideje: $\quad t=0,81-2,73 \mathrm{sec}$

- forgácsolás ideje: $\quad t_{c}=0,21-0,68$ sec

$\mathrm{Az}$ axiális forgácsolóerő $(\mathrm{Ff})$ mérése egy kétkomponensü kompakt dinamometerrel történt, amely nagy dinamikai szilárdsággal rendelkezik, így magas a sajátfrekvenciája, amely lehetővé teszi a kisebb dinamikus erőhatások mérését magas alapterheléseknél is.

Technikai adatok:

Megnevezés: KISTLER, 2 komponensü dinamométer

Típus: $9271 \mathrm{~A}$

Mérési tartomány:

- $\quad$ Ff $[\mathrm{kN}]:-5 \div 20$;

- $\quad \mathrm{Mc}[\mathrm{Nm}]:-100 \div+100$.

Érzékenység:

- $\quad \mathrm{Ff}[\mathrm{pC} / \mathrm{N}]:-2,02$;

- $\quad \mathrm{Mc}[\mathrm{pC} / \mathrm{N}]:-1,6$.

Linearitás: \%FSO: L 0,3

Üzemi hőmérséklet-tartomány, ${ }^{\circ} \mathrm{C}: 1-70$

A dinamometer által szolgáltatott jel erősítéséhez Kistler 5038 A2 típusú ipari töltéserösítőt használtunk, a mérési adatok feldolgozását Labview 9.0 szoftver segítségével végeztük.

\subsection{A kísérletek leírása}

A forgácsolási paraméterek forgácsolóeröre $\left(\mathrm{F}_{\mathrm{c}}\right)$ gyakorolt hatásának vizsgálatához 3 különböző fogásvétel $\left(a_{p}=0,5 ; 1 ; 1,5\right.$ $\mathrm{mm}$ ) és 3 különböző kettős löketszám $\left(\mathrm{n}_{\mathrm{k}}=22 ; 38 ; 74 \mathrm{kl} /\right.$ perc $)$, azaz átlagos forgácsoló sebesség $\left(\mathrm{v}_{\mathrm{cL}}=10,67 ; 20,91 ; 34,86\right.$ $\mathrm{m} /$ perc) beállítása mellett mértük $F_{c}$ értékét. A kísérletek során egyszerre mindig egy paraméter értékét változtattuk, a többit ál- landó értéken tartottuk, így 9 kísérleti beállítást vizsgáltunk.

A munkalöket alatt 0,0175 másodpercenként mértük $\mathrm{F}_{\mathrm{c}}$ értékét, tehát a forgácsoló sebességtől függően $\mathrm{n}_{\mathrm{k}}=22 \mathrm{kl} /$ perc-nél 39 $\mathrm{db}, \quad \mathrm{n}_{\mathrm{k}}=38 \mathrm{kl} /$ perc-nél $20 \quad \mathrm{db} \quad \mathrm{n}_{\mathrm{k}}=74$ $\mathrm{kl} /$ perc-nél $11 \mathrm{db}$ mérést végeztünk a szerszám forgácsoló mozgása során, majd ezekből az adatokból a forgácsolóerő átlagértékeit $\left(\mathrm{F}_{\mathrm{c}}\right)$ számoltuk, amelyeket az $\mathbf{1}$. táblázatban tüntettük fel. Méréseink szerint a forgácsolóerő a munkalöket (mdb hossza) mentén mintegy 5-12\%-ot változott.

A beállítási paraméterek figyelembevételével meghatároztuk a teljes lökethosszra vonatkoztatott átlagos forgácsoló sebességet $\left(\mathrm{v}_{\text {clöket }}\right)$, valamint a tényleges $\mathrm{mdb}$ hosszra vonatkoztatott átlagos forgácsoló sebességet $\left(\mathrm{v}_{\mathrm{cL}}\right)$ (1. táblázat).

A fogásvétel $\left(a_{p}\right)$ forgácsolóerőre $\left(F_{c}\right)$ gyakorolt hatását az 1. ábra, az átlagos forgácsoló sebesség $\left(\mathrm{v}_{\mathrm{cL}}\right)$ hatását a 2 . ábra mutatja be.

\subsection{Az eredmények értékelése}

$\mathrm{Az}$ átlagos forgácsoló sebesség $\left(\mathrm{v}_{\mathrm{cL}}\right)$ és a fogásvétel $\left(a_{p}\right)$ átlagos forgácsolóerőre gyakorolt hatására a következő megállapításokat tehetjük:

$A z$ átlagos forgácsolóerő $\left(F_{c}\right)$ a fogásvétellel közel arányosan nő $\mathrm{v}_{\mathrm{cL}}=10,67 \mathrm{~m} / \mathrm{p}$ átlagos forgácsoló sebességnél, azonban az átlagos forgácsoló sebesség növelésével a forgácsolóerő fogásvétellel való emelkedése egyre kisebb mértékü.

Míg 10,67 m/p-nél a fogátvétel 0,5 mm-ről 1,5 mm-re való növelésénél az átlagos forgácsolóerő 2,95-szörösége nő, addig $34,86 \mathrm{~m} / \mathrm{p}$-nél ugyanezen a tartományon $\mathrm{F}_{\mathrm{c}}$ már csak 2,3-szeresére emelkedik.

Méréseink igazolják a forgácsoláselméletből jól ismert összefüggést, mely szerint a forgácsolóerő a forgácskeresztmetszettel, ill. az azt meghatározó fogásvétellel arányosan változik. Azonban minél nagyobb sebességgel forgácsolunk, a forgácsolási ellenállás $\left(\mathrm{k}_{\mathrm{c}}\right)$ annál nagyobb mér- 
tékben csökken $[11,12]$ - ez magyarázza az átlagos forgácsoló erő, $\mathrm{F}_{\mathrm{c}}$ erőteljes csökkenését.

Amennyiben állandó fogásvétel $\left(a_{p}\right)$ mellett vizsgáljuk a forgácsoló sebesség $\left(\mathrm{v}_{\mathrm{cL}}\right)$ forgácsolóerőre gyakorolt hatását, akkor az alábbiakat figyelhetjük meg:

- $a_{\mathrm{p}}=0,5 \mathrm{~mm}$-nél $\mathrm{v}_{\mathrm{cL}}$ növelésével $F_{c}$ kismértékben nö;

- $a_{p}=1$ mm-nél $v_{c L}$ növelésével $F_{c}$ kismértékben csökken;

- $a_{p}=1,5 \mathrm{~mm}$-nél $v_{c L}$ növelésével $F_{c}$ csökkenése egyre erőteljesebb.
Az $\mathbf{a}_{\mathbf{p}} \geq 1 \mathrm{~mm}$ fogásvételnél vcL növelése egyre erőteljesebb forgácsolóerő csökkenéshez vezet (elsősorban a forgácsolási ellenállás mérséklődése miatt), ezért $\mathrm{Fc}$ szempontjából a vizsgált sebességtartományban vcL növelése kedvező.

A forgácsoló erő a lökethossz mentén számottevően változik. A löket mentén az erőingadozás mellett a forgácsoló erő lassú növekedése figyelhető meg, különösen nagyobb sebességeknél jelentősebb a forgácsolóerő növekedése.

Erre magyarázatként a nem kellő merevségü befogadás szolgálhat.

\begin{tabular}{|c|c|c|c|}
\hline \multirow{3}{*}{$\begin{array}{c}\text { Fogásvétel } \\
\mathbf{a}_{\mathbf{p}} \text { [mm] }\end{array}$} & \multicolumn{3}{|c|}{ Átlagos forgácsolóerö, $\mathbf{F}_{\mathbf{c}}[\mathbf{N}]$} \\
\cline { 2 - 4 } & $\begin{array}{c}\mathrm{n}_{\mathrm{k}}=22 \mathrm{kl} / \text { perc } \\
\mathrm{v}_{\text {clöket }}=8,8 \mathrm{~m} / \text { perc } \\
\mathrm{v}_{\mathrm{cL}}=10,67 \mathrm{~m} / \text { perc }\end{array}$ & $\begin{array}{c}\mathrm{n}_{\mathrm{k}}=38 \mathrm{kl} / \text { perc } \\
\mathrm{v}_{\text {clöket }}=15,2 \mathrm{~m} / \text { perc } \\
\mathrm{v}_{\mathrm{cL}}=20,91 \mathrm{~m} / \text { perc }\end{array}$ & $\begin{array}{c}\mathrm{n}_{\mathrm{k}}=74 \mathrm{kl} / \text { perc } \\
\mathrm{v}_{\text {clöket }}=29,6 \mathrm{~m} / \text { perc } \\
\mathrm{v}_{\mathrm{cL}}=34,86 \mathrm{~m} / \text { perc }\end{array}$ \\
\hline 0,5 & 296 & 307 & 320 \\
\hline 1,0 & 580 & 551 & 547 \\
\hline 1,5 & 874 & 812 & 738 \\
\hline
\end{tabular}

1. táblázat A gyalulási kísérletek során mért erő értékei

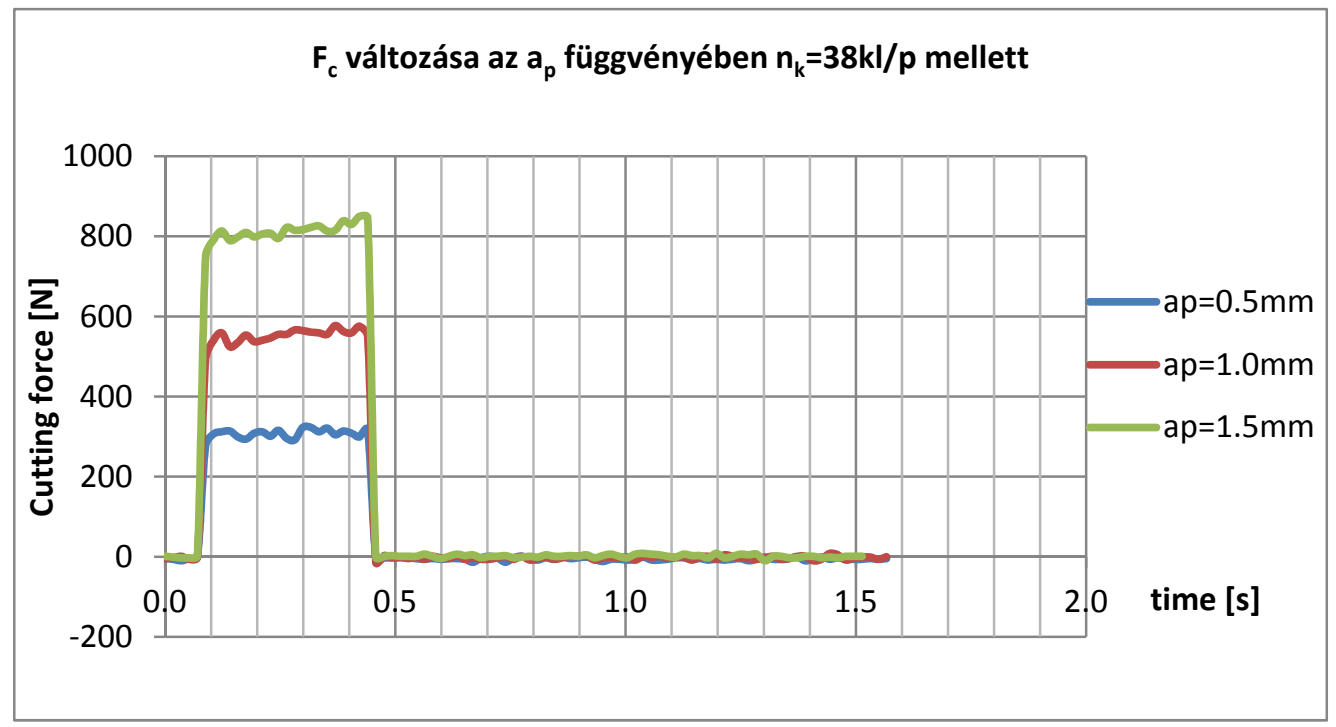

1.ábra. A fogásvétel $\left(a_{p}\right)$ forgácsolóerőre $\left(F_{c}\right)$ gyakorolt hatása 


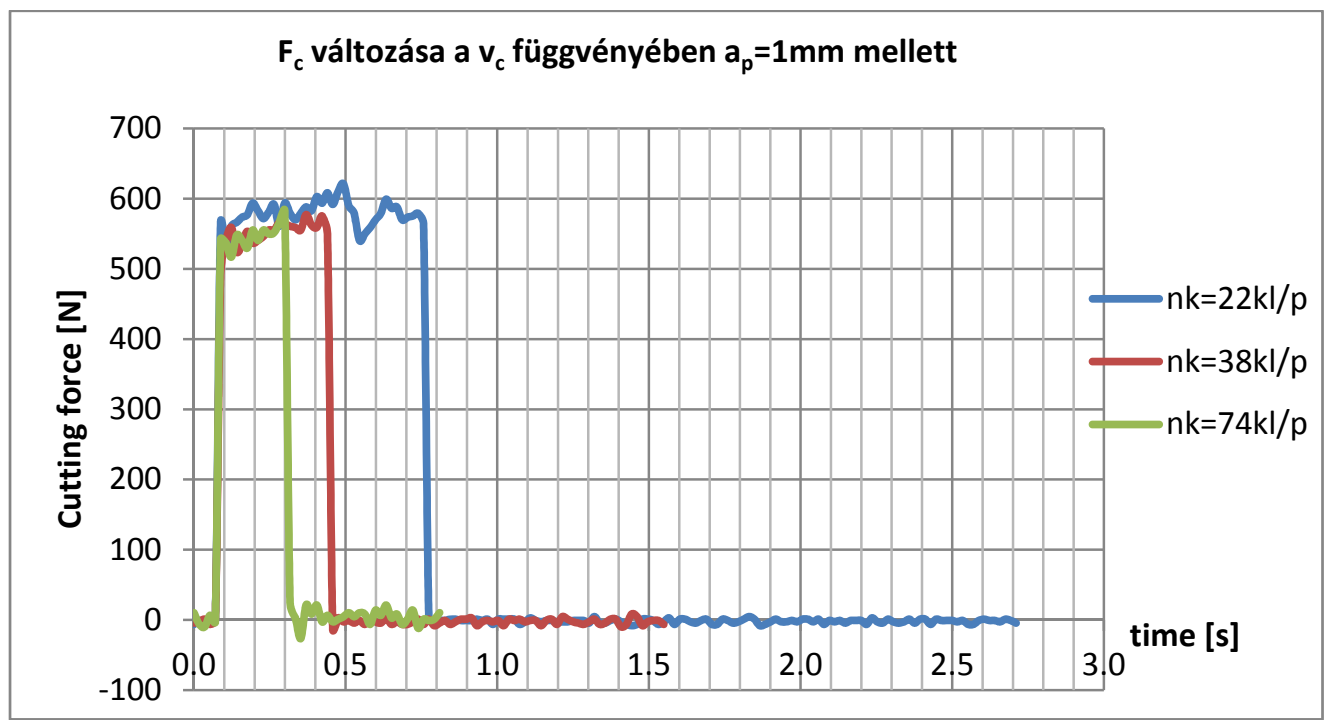

2.ábra. Az átlagos forgácsoló sebesség $\left(v_{c L}\right)$ forgácsolóeröre $\left(F_{c}\right)$ gyakorolt hatása

\subsection{A forgácsolási folyamat fizikai mo- dellezése}

A forgácsoló szerszám és a munkadarab diszkrét modelljét lineáris tetraéder elemekből építettük fel (3. ábra). A számítás során a munkadarab esetén adaptív újrafelosztást alkalmaztunk, ami a nagy alakváltozások modellezésénél szükségszerü. Az újrafelosztás esetén az elemméret csökkentését is megengedtük azokon a helyeken, ahol az alakváltozás nagy.

$\mathrm{Az}$ érintkezési feladat során a súrlódást állandó súrlódási együtthatóval, a Coulomb-féle súrlódási modell arkusz tangens közelítésével vettük figyelembe. Az érintkezési tolerancia értékét automatikusan változtattuk, így az $0,01 \mathrm{~mm}$ nagyságrendjében változott.
A hőmérséklet változását, ami a súrlódási munka, az alakváltozási munka, valamint a hőelvezetési és sugárzási folyamatok eredménye, figyelembe vettük.

A szimuláció során kis időlépéseket alkalmaztunk az igen gyorsan változó célfüggvények miatt.

A szimulációt egy általános célú kereskedelmi szoftver segítségével végeztük el [8].

A 4. ábra a forgácsolóerő változását mutatja az idő függvényében $a_{p}=1 \mathrm{~mm}$ fogásmélység és $\mathrm{V}_{\mathrm{CL}}=10,67 \mathrm{~m} /$ perc forgácsolási sebesség esetén. Az 1. táblázat első oszlopának középső adatával, amely ugyanezen forgácsolási paraméterek mellett mérhető, jó egyezés figyelhető meg. Ugynezt mutatja a 4. ábra grafikonja. 


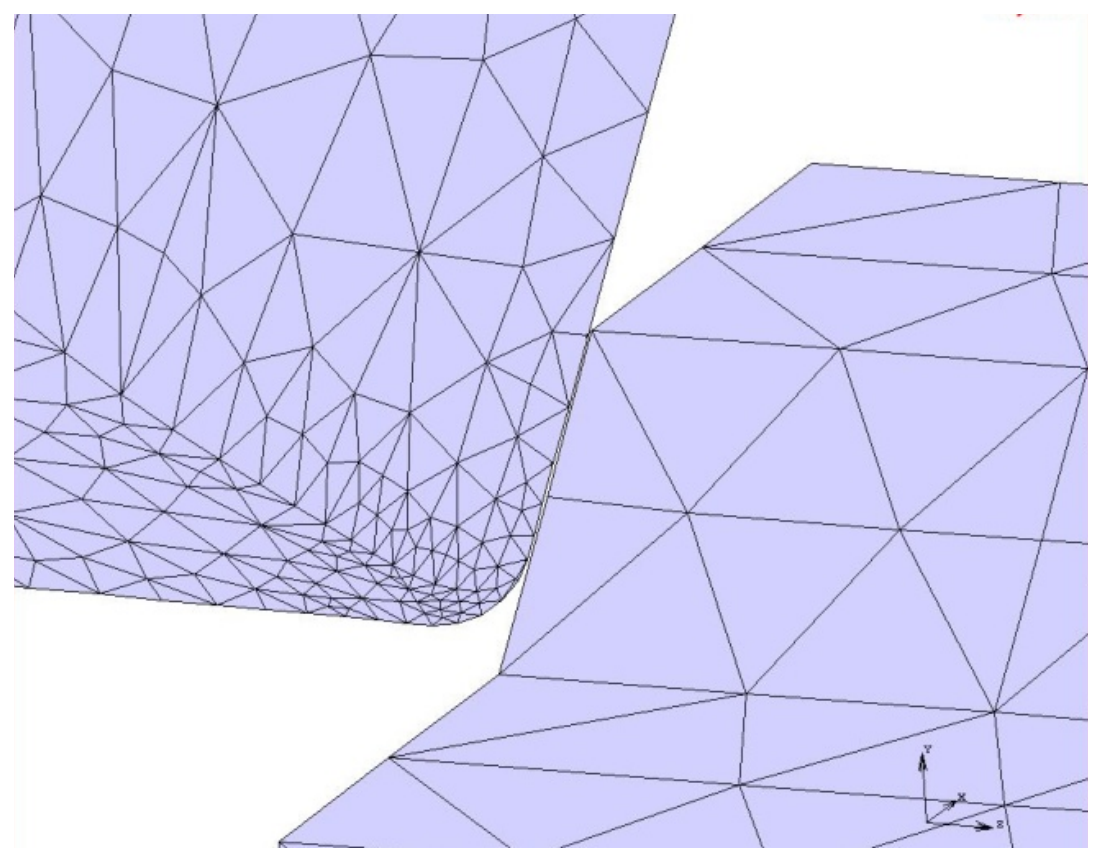

3.ábra. A szerszám és amunkadarab diszkrét modellje

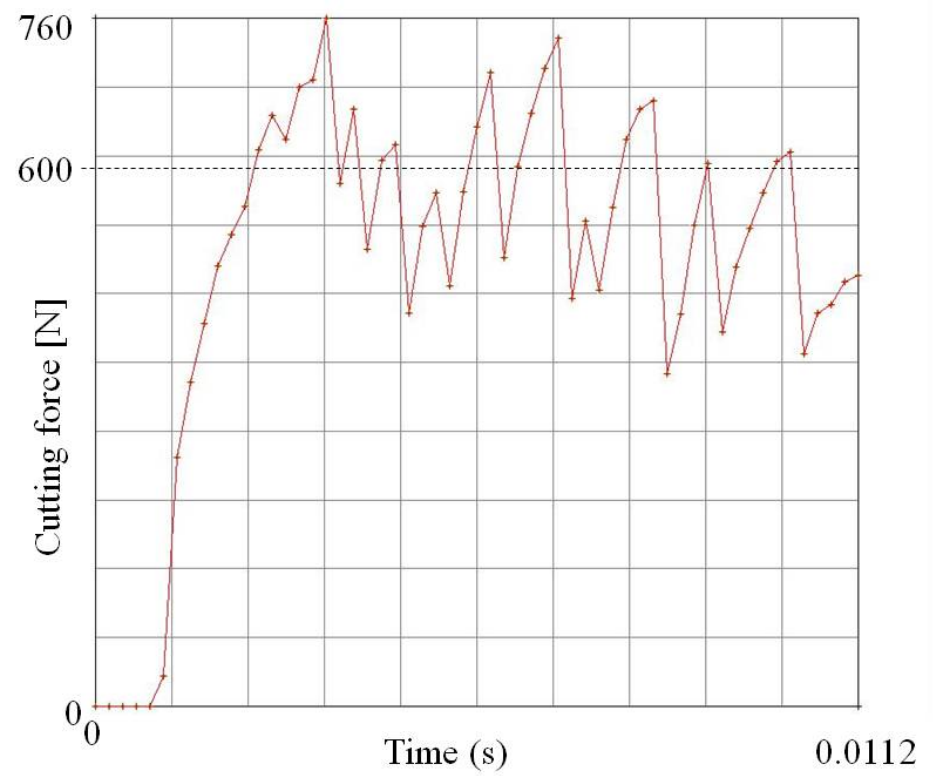

4.ábra. A szimulációval kapott forgácsolóerő nagysága $a_{p}=1 \mathrm{~mm}$ és $v_{c L}=10,67 \mathrm{~m} /$ perc esetén 


\section{Következtetések}

A dolgozatunkban leírt modellszámítás eredményei azt mutatják, hogy a forgácsleválasztás során fellépő jelenségek figyelembe vételével jó közelítéssel leírható a forgácsolás folyamata.

A méréssel kapott forgácsolóerő értékét a szimuláció jó közelítéssel adta meg.

\section{Szakirodalmi hivatkozások}

[1] Strenkowski, J. S., Carroll, J.T.: A finite element model of orthogonal metal cutting. Journal of Engineering for Industry 107 (1985) 347-354.

[2] Hashemi, J., Tseng, A. A., Chou, P. C.: Finite element modelling of continuous and segmental chip formation in high speed orthogonal machining. Journal of Materials Engineering and Performance 3 (6) (1994) 712-721.

[3] Shih, A. J.: Finite element analysis of orthogonal metal cutting mechanics. International Journal of Machine Tools Manufacturing 36 (1996) 255-273.

[4] Ceretti, E., Fallbohmer, P., WU, W. T., Altan, T.: Application of $2 D$ FEM to chip formation in orthogonal cutting. Journal of
Materials Processing Technology 59 (1996) 169-180.

[5] A.R., Machado, M.F., Motta, M.B., Da Silva: Performance of Synthetic and Mineral Soluble Oil When Tuming AISI 8640 Steel. Trans. ASME, Vol. 119, 580-586. 1997

[6] Wu, J.-S., Dillon, O. W., Lu, W. Y.: ThermoViscoplastic Modelling of Machining Process Using a Mixed FEM. Trans. ASME 1996, Vol. 118, pp.:470-481.

[7] Shaw, M. C.: Metal Cutting Principles. Oxford University Press, Oxford, 1984.

[8] Marc Volume A, Theory and User Information. MSC Software Inc., 2010.

[9] Zienkiewicz, O. C.; Taylor, R. L.; ZHU, J. $\mathrm{Z}$.: The finite element method, its basis and fundamentals. Elsevier Butterwort-Heineman Linacre House, Oxford, 2005, ISBN 0-75066320

[10] Dudás I., Lierath F., Varga Gy.: Környezetbarát technológiák a gépgyártásban. Forgácsolás szárazon, minimális hütéssel-kenéssel. Müszaki Kiadó, Budapest, 2010. 308, ISBN 987-963-166500-0

[11] Dudás I.: Gépgyártástechnológia $\quad I$. Müszaki Könyvkiadó, Budapest, 2011.

[12] Gyáni K.: Gépgyártástechnológia alapjai I. Tankönyvkiadó, Budapest, 1978. 